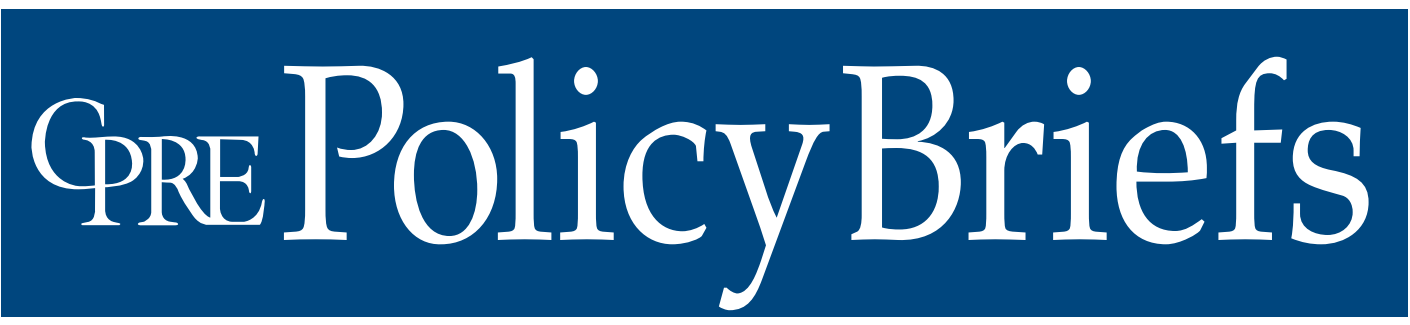

Reporting on Issues and Research in Education Policy and Finance

\section{Redesigning School Finance Systems: Lessons from CPRE Research}

By Allan Odden

\section{Introduction}

CPRE and particularly the CPRE group at the University of Wisconsin-Madison have been working on school finance redesign since 1990. The issue that has driven this effort has been the goal of state standardsbased education reform and, more recently, of the federal No Child Left Behind (NCLB) Act to teach all students to high standards. This goal has shifted the orientation of the education system from inputs to outcomes - student achievement to rigorous performance standards-with an attendant accountability focus at the school site. In the broader school finance community, this focus has induced a shift from "equity" to "adequacy," for both litigation and policy. Though adequacy narrowly seeks to identify the level of dollars needed to produce a desired level of student achievement, its more general objective is to redesign the finance system to link resource levels and resource-use practices more directly to student learning.

This policy brief describes how CPRE has approached this agenda over the past decade and a half, and reveals how our current finance research has begun to explicitly link the level and use of resources with strategies that districts and schools can deploy to literally double student performance over a 5- to 10-year period. During the time period over which this finance research agenda has evolved, we believe it has succeeded in linking school finance equity and adequacy, both by aligning effective allocation and use of resources to the most powerful and comprehensive schoolbased strategies to boost student learning and by identifying strategies for how and how much to pay teachers.
This summary of CPRE school finance research and its policy conclusions addresses the following topics:

- How education dollars are spent

- Tracking education resources at the school level and by educational strategy

- Education resource reallocation

- Toward school finance adequacy

- Using resources to double student achievement

- Use of dollars after a school finance reform

- Pricing adequacy recommendations and enhancing teacher compensation

- Policy and practice implications

\section{How the Education Dollar Is Spent}

We knew that accomplishing the student achievement goals of state and federal reforms required using the education dollar more effectively. Thus, we developed several efforts beginning in 1990 to better understand how the education dollar was typically being spent. This work led to the following conclusions (Odden \& Picus, 2007):

a. There has been a steady increase in education dollars per pupil, which, after adjusting for inflation, have risen on average about $3.5 \%$ annually over the past 100 years.

b. Today, about $61 \%$ of the education dollar is spent on instruction, with $10 \%$ on administration (5-6\% at the site and 4$5 \%$ at the central office), $10 \%$ on instructional and pupil support, $10 \%$ on
February 2007

RB-50

Graduate School

of Education

University of

Pennsylvania

\section{Consortium for Policy Research in Education}

University

of Pennsylvania

Teachers College, Columbia University

Harvard University

Stanford University

University

of Michigan

University of

Wisconsin-Madison

Northwestern

University 
operations and maintenance, 5\% on transportation, and $5 \%$ on food and miscellaneous items. This pattern is remarkably similar for districts with very different demographics and number of pupils. ${ }^{1}$

c. Further, over the past 50 years, the percent of expenditures spent on the classroom-or instruction-has remained consistent at about $60-61 \%$.

d. There has been tremendous change in the composition of those classroom/instructional expenditures. Whereas 50 years ago the vast bulk of such expenditures were for regular classroom teachers (the grade-level teachers in elementary schools and math, science, reading/writing, history, and language teachers in secondary schools), today significant portions of such expenditures are spent on specialist teachers (art, music, family and consumer education, vocational education, health, physical education, etc.) and for extra services for struggling studentsthose from lower-income backgrounds, those learning English, and those with disabilities. More funding has also been used to employ instructional aides.

e. There is no indication that administration consumes large sums of money. Administrative expenditures have remained constant-about $5-6 \%$ for site administration and about $4-5 \%$ for central-office administration. Interestingly, the latter figures are lower for the largest districts in the country, such as New York City, Chicago, and Los Angeles.

f. Though revenues per pupil increased consistently over time, there has not been a commensurate increase in student achievement, although more students are being served in schools and performance at the basic levels has risen. Although more services have been provided to students with special needs, perhaps ensuring that overall achievement did not drop, the consistent rise in spending per pupil was not accompanied by a similar rise in student performance, at least over the past 30-40 years. The result means that current education goals are not
The research reported in this brief was conducted by the Consortium for Policy Research in Education (CPRE) and funded by the Institute of Education Sciences, United States Department of Education, under Grant No. R308A960003. Opinions expressed in this Brief are those of the authors and do not necessarily reflect the views of the Institute of Education Sciences, the United States Department of Education, CPRE, or its institutional members.

likely to be met without determining how better to use school resources.

Though these findings were a good first step in understanding how the education dollar was used, we decided that additional information was needed. As we indicate below, we have concluded that the major productivity issues in education have to do with how resources within the instructional function are used. For this as well as other reasons, we are not bullish with the notion to simply boost the percentage spent on instruction, i.e., the " $65 \%$ solution." Unless current and any new resources within the instructional function are spent more effectively, increasing the portion spent on instruction will be unlikely to impact student learning. To put the above findings into a more understandable context, we suggested that a different, and perhaps more helpful, way to understand how the educational dollar is spent is to think of it as divided into three portions (Odden \& Picus):

a. One portion for core instructional services (grade-level teachers in elementary schools and core subject teachersmathematics, science, language arts/ reading/writing, social studies, and foreign language - in secondary schools), professional development, and site administration. These would be considered the "line" resources in education.

b. Another portion for additional instruction, as well as instructional- and pupilsupport services: specialist teachers for subjects such as art, music, career/technical, and physical education; compensatory, special, and bilingual education services; guidance counselors, social workers, psychologists, family-outreach personnel; and instructional-support personnel such as librarians. These are 
the "support" resources in education as their purpose is to help the education system accomplish the core goal of student achievement in the core subjects.

c. A third portion for necessary "overhead" including operation and maintenance of schools (heating, cooling, cleaning, fixing, etc.), transportation, food services, and central-office administration (the superintendent's office, the business and personnel offices, and school board services).

The policy and practice issues, then, become whether expenditures in any of the three "portions" of education resources can be more productive, either by attaining current achievement with less money, or by spending the extant money more effectively and boosting results, with a focus on the latter given the performance challenges for schools.

\section{Tracking Resources}

Although it was becoming widely accepted that professional development was a key catalyst for changing classroom practice and improving student learning, little was known about how much districts and schools spent on professional development, and on what types. When we looked across existing studies, we found differences in terminology that prevented us from being able to compare costs across studies. These shortcomings led us to develop a framework for collecting expenditure data on investments in professional development (Odden, Archibald, Fermanich, \& Gallagher, 2002). The framework includes six cost elements: 1) teacher time, 2) training and coaching, 3) administration, 4) materials, equipment and facilities, 5) travel and transportation, and 6) tuition and conference fees. This professional development cost structure provides a way to identify, calculate, and analyze the professional-development resources that districts or schools make available to teachers at a given school site; the framework can also be used to identify the full costs of any specific professional development program. Teacher time, trainers, and coaches comprise the largest components of professional development costs.

We have used the framework to identify the costs and foci of professional development in several large cities (Fermanich, 2002; Miles, Odden, Archibald, \& Fermanich, 2004; Gallagher, 2002; Archibald \& Gallagher, 2002).
These studies found that the large districts studied were investing between $\$ 4,000$ and $\$ 8,000$ per teacher per year in professional development, with the higher numbers associated with more pupil-free days or summer institutes for training. The studies also found that the professional development strategies were generally a mile wide and an inch deep, not focused very much on core subjects, and had little impact on teachers' instructional practice. A similar study of professional development investments in a smaller, rural district found much lower professional development investments (Thayer, 2004).

The primary implication from this research is that districts should first conduct a professional-development fiscal audit to fully understand the fiscal size of their current investments in professional development. Cincinnati, Atlanta, Boston, Chicago, and Minneapolis are examples of districts that have used the framework to conduct such audits.

The utility of having a detailed framework for capturing expenditures for professional development led to our developing a framework for capturing all school-level expenditures. Thus, we developed a new fiscal reporting structure that could provide the type of detailed resource-use information at the school level that indicated more specifically how resources were used. Our system reports educational resource use at the school and district level by their educational strategy (Odden, Archibald, Fermanich, \& Gross, 2003). One major objective for the expenditure framework was to "unpack" the instructional category and report spending of dollars by educational strategy such as core instruction, specialist instruction, professional development, and types of extra help for students with special needs to achieve standards. The framework also includes several other nondollar indicators, each of which provides additional information about resource use, such as number of minutes allocated for reading and math instruction in elementary schools, class sizes, and percentage of core versus elective classes in high schools. The goal was to provide a richer and more detailed report on how the education dollar was used within the instructional category and at the school level.

As we discuss more below, we have used this school-level reporting structure to assess typical resource use in schools, to study how schools use resources after a school finance 
adequacy reform, and to analyze resource use practices in the context of instructional improvement strategies.

\section{Reallocating Dollars at the School Level}

Having better knowledge of how schools use resources is the first step toward using those resources more productively. A second step concerns how those dollars might be reallocated to more productive uses. Because the U.S. education system educates only about one-third of the nation's students to a rigorous proficiency standard (National Center for Education Statistics, 2005), the stark reality of the goal of teaching all, or nearly all, students to high standards requires doubling or tripling student academic achievement, and it is unlikely that there will be a commensurately large increase in dollars. ${ }^{2}$ So, to accomplish this achievement goal, schools will need to restructure themselves to more powerful educational strategies and, in the process, reallocate all dollars to their new and more effective educational visions.

However, the dominant assumption among most educators has been that because education is "labor" intensive, it cannot engage in resource reallocation strategies. Thus, we focused research attention on the topic of resource reallocation and the questions of whether resource reallocation can be done in education, and if so, how? Contrary to the predictions of many, we found numerous examples of schools that had dramatically reallocated their resources and usually for the purpose of improving student performance. From that research, we created about a dozen case studies of schools-urban suburban and rural-that had reallocated resources and in the process used teachers, time, and dollars both differently and more productively. (Odden \& Archibald, 2001a; Goertz \& Hess, 1998; Goertz \& Duffy, 1999; Miles \& Darling-Hammond, 1998; Odden, Archibald, \& Tychsen, 2000; Odden \& Archibald, 2000, 2001b; http://www.wcer.wisc.edu/cpre/ finance/research/reallocation.php).

From these cases, we found that resource reallocation was focused largely on the second "portion" of dollars-the resources in the "support" portion of the education dollar. Dri- ven largely by displeasure with their students' performance, and in most cases more specifically the performance of their students needing extra help (those from lower income or ELL backgrounds or with disabilities), the schools redesigned their entire schools' education program and through both restructuring and resource reallocation transformed themselves into different and more productive educational organizations. In the process, they tended to expand time spent on core academic subjects, often provided lower class sizes for those subjects, invested much more in professional development for teachers, and many times provided more intensive and much more effective extra help for struggling students, such as one-to-one tutoring. We found that the resource reallocation process followed the procedures of large-scale organizational change (Mohrman, 1994; Odden \& Archibald, 2001a), which made sense as the schools restructured themselves as part of the underlying process of their resource reallocation.

These findings were confirmed by our analysis of the New American Schools series of whole school designs-what many called "comprehensive school reforms"- that aimed to teach students to high state and district performance standards (see Odden, 1997; Odden \& Busch, 1998). We found that all of the designs had a set of resources that ultimately aligned well with our expenditure reporting structure and could be funded with the national average expenditure per pupil. In this research, we found that whole school designs generally used resources differently than traditional schools - the designs, like the schools that had reallocated resources, focused more resources on the core subjects, often provided smaller class sizes for these subjects, invested in substantial ongoing professional development (including school-based instructional coaches) so teachers could acquire the skills to effectively teach the curriculum in the various designs, and provided extra help for struggling students such as one-to-one tutoring. Subsequent research showed that many but not all designs produced higher levels of student achievement than typical schools (Borman, Hewes, Overman, \& Brown, 2003). 


\section{Toward School Finance Adequacy}

Ultimately, however, the costs of these and even more powerful whole-school designs needed to be aggregated into district and state costs, and then converted into a state school finance policy that provides each district and each school with an "adequate" amount of resources. Building on the previous research on the costs of more effective school-wide strategies, Allan Odden and Larry Picus developed the "evidence-based" approach to school finance adequacy. This approach summarizes research and best practices evidence on the major dimensions of schools that have cost implications-school size, class size, core instruction, specialist instruction, extra help for struggling students, professional development, administration, etc. - and identifies for each school in a state a level of "adequate" resources. These resources are then combined with district-level functions for operations and maintenance, transportation, food services, and central administration to determine an "adequate" resource level for each district in the state. ${ }^{3}$ Furthermore, although most adequacy studies simply "carry forward" expenditures for operations and maintenance, central office, transportation, and food services, the 2006 Picus and Odden adequacy analyses in Washington and Arkansas reviewed the literature of the effectiveness and efficiency of these functions and used standards to estimate adequate resources for these functions as well. Table 1 indicates the results of such an adequacy study for the state of Wisconsin.

In states that have adequacy studies, the results are then incorporated into newly designed school finance formulas. In every instance that we know about, the new formula is some version of a new foundation formula. In Wyoming, the foundation amount for each district was determined by first applying the recommendations in that state's Table 1 to

Table 1. Recommendations for Adequate Resources for Prototypical Wisconsin Elementary, Middle, and High Schools

\begin{tabular}{|c|c|c|c|}
\hline School Element & Elementary Schools & Middle Schools & High Schools \\
\hline \multicolumn{4}{|l|}{ School Characteristics } \\
\hline School configuration & K-5 & $6-8$ & $9-12$ \\
\hline Prototypic school size & 432 & 450 & 600 \\
\hline Class size & $\begin{array}{l}\text { K-3: } 15 \\
4-5: 25 \\
\end{array}$ & 6-8: 25 & 9-12: 25 \\
\hline Full-day kindergarten & Yes & NA & NA \\
\hline $\begin{array}{l}\text { Number of teacher } \\
\text { work days }\end{array}$ & $\begin{array}{l}190 \text { teacher work days, } \\
\text { so an increase of } 5 \text { days }\end{array}$ & $\begin{array}{l}190 \text { teacher work days, } \\
\text { so an increase of } 5 \text { days }\end{array}$ & $\begin{array}{l}190 \text { teacher work days, } \\
\text { so an increase of } 5 \text { days }\end{array}$ \\
\hline$\%$ Disabled & $14.5 \%$ & $14.5 \%$ & $14.5 \%$ \\
\hline $\begin{array}{c}\% \text { Poverty } \\
\text { (free \& reduced lunch) }\end{array}$ & $30 \%$ & $30 \%$ & $30 \%$ \\
\hline$\%$ ELL & $\sim 10 \%$ & $\sim 10 \%$ & $\sim 10 \%$ \\
\hline$\%$ Minority & $21.2 \%$ & $21.2 \%$ & $21.2 \%$ \\
\hline \multicolumn{4}{|l|}{ Personnel Resources } \\
\hline 1. Core teachers & 24 & 18 & 24 \\
\hline 2. Specialist teachers & $\begin{array}{l}20 \% \text { more: } \\
4.8\end{array}$ & $\begin{array}{l}20 \% \text { more: } \\
3.6\end{array}$ & $\begin{array}{l}33 \% \text { more: } \\
8.0\end{array}$ \\
\hline $\begin{array}{l}\text { 3. Instructional Facilitators } \\
\text { and Mentors }\end{array}$ & 2.2 & 2.25 & 3.0 \\
\hline 4. Tutors for struggling students & $\begin{array}{c}\text { one for every } 100 \\
\text { poverty students: } \\
1.30\end{array}$ & $\begin{array}{c}\text { one for every } 100 \\
\text { poverty students: } \\
1.35\end{array}$ & $\begin{array}{c}\text { one for every } 100 \\
\text { poverty students: } \\
1.8\end{array}$ \\
\hline
\end{tabular}

(table continued on next page)

${ }^{3}$ All adequacy studies as discussed below and in Odden (2003b) identify resources at the school and district levels and then aggregate them 


\begin{tabular}{|c|c|c|c|}
\hline School Element & Elementary Schools & Middle Schools & High Schools \\
\hline \multicolumn{4}{|l|}{ Personnel Resources (continued) } \\
\hline 5. Teachers for ELL students & $\begin{array}{c}\text { An additional } 1.0 \text { teachers } \\
\text { for every 100 ELL students } \\
0.43\end{array}$ & $\begin{array}{c}\text { An additional } 1.0 \text { teachers } \\
\text { for every } 100 \text { ELL students } \\
0.45\end{array}$ & $\begin{array}{c}\text { An additional } 1.0 \text { teachers } \\
\text { for every } 100 \text { ELL students } \\
0.60\end{array}$ \\
\hline 6. Extended Day & 1.1 & 1.125 & 1.5 \\
\hline 7. Summer School & 1.1 & 1.125 & 1.5 \\
\hline 8. Alternative Schools & NA & NA & $\begin{array}{l}1 \text { AP plus } 1 \text { teacher for every } \\
7 \text { alternative school students }\end{array}$ \\
\hline $\begin{array}{l}\text { 9. Learning and mild } \\
\text { disabled students }\end{array}$ & $\begin{array}{c}\text { Additional } 3 \text { professional } \\
\text { teacher and } 1.5 \text { aide positions }\end{array}$ & $\begin{array}{l}\text { Additional } 3 \text { professional } \\
\text { teacher and } 1.5 \text { aide positions }\end{array}$ & $\begin{array}{c}\text { Additional } 3 \text { professional } \\
\text { teacher and } 2 \text { aide positions }\end{array}$ \\
\hline 9. Severely disabled students & $\begin{array}{l}100 \% \text { state reimbursement } \\
\text { minus federal funds }\end{array}$ & $\begin{array}{l}100 \% \text { state reimbursement } \\
\text { minus federal funds }\end{array}$ & $\begin{array}{l}100 \% \text { state reimbursement } \\
\text { minus federal funds }\end{array}$ \\
\hline 10. Teachers for gifted students & $\$ 25 /$ student & $\$ 25 /$ student & $\$ 25 /$ student \\
\hline 11. Vocational Education & NA & NA & $\begin{array}{c}\text { No additional for } \\
\text { career/technical education }\end{array}$ \\
\hline 12. Substitutes & 10 days per teacher & 10 days per teacher & 10 days per teacher \\
\hline 13. Pupil support staff & $\begin{array}{l}1 \text { for every } 100 \\
\text { poverty students: } \\
1.3 \text { total }\end{array}$ & $\begin{array}{l}1 \text { for every } 100 \text { poverty } \\
\text { students plus } 1.0 \\
\text { guidance } / 250 \text { students } \\
3.15 \text { total }\end{array}$ & $\begin{array}{l}1 \text { for every } 100 \text { poverty } \\
\text { students plus } 1.0 \\
\text { guidance/ } 250 \text { students } \\
4.2 \text { total }\end{array}$ \\
\hline 14. Noninstructional Aides & 2.0 & 2.0 & 3.0 \\
\hline 15. Librarians/media specialists & 1.0 & 1.0 & $\begin{array}{c}1.0 \text { librarian } \\
1.0 \text { library technician }\end{array}$ \\
\hline 16. Principal & 1 & 1 & 1 \\
\hline 17. School Site Secretary & $\begin{array}{l}\text { 1.0 Secretary and } \\
1.0 \text { Clerical }\end{array}$ & $\begin{array}{c}\text { 1.0 Secretary and } \\
1.0 \text { Clerical }\end{array}$ & $\begin{array}{l}\text { 1.0 Secretary and } \\
3.0 \text { Clerical }\end{array}$ \\
\hline \multicolumn{4}{|l|}{ Dollar per Pupil Resources } \\
\hline 18.Professional development & $\begin{array}{c}\text { Included above: } \\
\text { Instructional facilitators } \\
\text { Planning \& prep time } \\
10 \text { summer days } \\
\text { Additional: } \\
\$ 100 / \text { pupil for other PD } \\
\text { expenses-trainers, conferences, } \\
\text { travel, etc. }\end{array}$ & $\begin{array}{c}\text { Included above: } \\
\text { Instructional facilitators } \\
\text { Planning \& prep time } \\
10 \text { summer days } \\
\text { Additional: } \\
\text { \$100/pupil for other PD } \\
\text { expenses-trainers, conferences, } \\
\text { travel, etc. }\end{array}$ & $\begin{array}{c}\text { Included above: } \\
\text { Instructional facilitators } \\
\text { Planning \& prep time } \\
10 \text { summer days } \\
\text { Additional: } \\
\$ 100 / \text { pupil for other PD } \\
\text { expenses-trainers, conferences, } \\
\text { travel, etc. }\end{array}$ \\
\hline 19. Technology & $\$ 250 /$ pupil & $\$ 250 /$ pupil & $\$ 250 /$ pupil \\
\hline $\begin{array}{l}\text { 20. Instructional materials, } \\
\text { equipment, including textbooks, } \\
\text { and formative assessments }\end{array}$ & \$165/pupil & \$165/pupil & \$200/pupil \\
\hline 21. Student activities & \$200/pupil & \$200/pupil & $\$ 250 /$ pupil \\
\hline \multicolumn{4}{|l|}{ Central Office Expenditures } \\
\hline 22. Central Administration & $\$ 658$ per pupil & $\$ 658$ per pupil & $\$ 658$ per pupil \\
\hline 23. Operations and Maintenance & $\begin{array}{l}\text { 2004-05 expenditures: } \\
\text { \$938 per pupil }\end{array}$ & $\begin{array}{l}\text { 2004-05 expenditures: } \\
\text { \$938 per pupil }\end{array}$ & $\begin{array}{l}\text { 2004-05 expenditures: } \\
\$ 938 \text { per pupil }\end{array}$ \\
\hline 24. Transportation & $\begin{array}{l}\text { Actual expenditures } \\
\text { replaced in the near future } \\
\text { by a standards-based formula }\end{array}$ & $\begin{array}{c}\text { Actual expenditures } \\
\text { replaced in the near future } \\
\text { by a standards-based formula }\end{array}$ & $\begin{array}{c}\text { Actual expenditures } \\
\text { replaced in the near future } \\
\text { by a standards-based formula }\end{array}$ \\
\hline 25. Food Services & Should be self-supporting. & Should be self-supporting. & Should be self-supporting. \\
\hline 26. Debt Service & A 20 percent equalizing formula & A 20 percent equalizing formula & A 20 percent equalizing formula \\
\hline
\end{tabular}


each school in the district, aggregating those to a school-based total for the district, and then adding in the district level resources to determine the "adequate" level of funding for each district. Since the recommendations were applied to the precise sizes and demographics of each school and district, the result was a different adequate amount for each district. By contrast, Arkansas took its version of Table 1 and calculated an average expenditure per pupil for the state, which was then used in a foundation program with that adequate amount as the new foundation expenditure level. In addition, Arkansas provided categorical aid for students from poverty and ELL backgrounds. ${ }^{4}$

Odden, Goetz, and Picus (2007) show that the average per-pupil costs of the resources in the evidence-based adequacy model are very close to the national average expenditure per pupil. This suggests that many districts in many states have the resources to deploy these strategies. Although more research and information is clearly needed, we would argue that schools and districts would be wise to use the strategies in the evidence-based model as research shows that those strategies-and especially the small classes in grades $\mathrm{K}-3$, the significant investments in professional development including the school-based coaches, and the 1-1 tutoring - do boost student learning (see next section on doubling student performance). Thus, our perspective is that if schools and districts have the dollars to support the strategies in the evidence-based model, implementing those strategies, as the schools that have doubled student performance have done, would be a good initial strategy for using their resources in the most effective ways.

\section{Using Resources to Double Student Performance}

In Washington, we were asked not only to conduct a school finance adequacy analysis using the evidence-based approach but also to conduct an adequacy analysis using the successful district approach. Typically, the successful district approach first identifies a set of student outcome variables of interest to the policy community, then finds districts that educate students to those outcome levels, and finally calculates the weighted average expenditure per pupil of those districts, with that expenditure figure being the proposed "adequate" level of education spending.

We studied several schools in the successful districts with the goal of determining how those schools used resources as well as how those resource-use practices were linked to the schools' instructional improvement strategies, which had resulted in the high levels of student performance. We found multiple examples of schools that had "doubled" student performance ${ }^{5}$ over the previous 4 to 7 years, including rural and urban schools, schools in large and small districts, and schools with high and low concentrations of students from lower income backgrounds (Fermanich, Mangan, Odden, Picus, Gross, \& Rudo, 2006). Studies of similar schools or districts that had doubled performance in Wisconsin (Odden, Picus, Archibald, Goetz, Mangan, \& Aportela, 2007) found schools all over the state and in very different socio-demographic contexts that had "doubled" student performance, including one district in which two elementary schools had doubled the percentage of students scoring at the "advanced" levels on state tests in mathematics.

\footnotetext{
${ }^{4}$ In the forthcoming fourth edition of the top school finance text, School Finance: A Policy Perspective, Odden and Picus (2007) include the entire evidence-based analysis in a chapter at the beginning of the book and show how the results can be used in various school funding structures.

${ }^{5}$ We use the term "double performance" to indicate more generally schools and districts that have dramatically improved student performance primarily on state tests. Sometimes they have literally doubled performance, such as doubling the percentage of students scoring at or above proficiency. Sometimes, performance of subgroups, such as low income and minority students, doubles. Sometimes, performance at or above the advanced levels is the performance that doubles. We would use the term "doubling" for the district that hiked performance from $65 \%$ at or above proficiency to $95 \%$. We do not imply, though, that doubling is all that needs to be accomplished; in some cases, performance must triple or more. The argument is that a first bold step towards accomplishing the ambitious student performance goals of state standards based reform or of NCLB, and of using resources effectively, would be a doubling of performance from current levels, and even that a first approximation of "adequate" resources might be resources that would allow schools to double student performance.
} 
These powerful examples of actual districts or schools doubling performance, and in many cases reducing the achievement gap, show that there is knowledge about how to dramatically improve student academic achievement. Further, and rather surprisingly, we found that the schools followed a strongly similar set of steps in their doubling performance strategies. These schools:

1) Set high goals, many times trying to educate $90-95 \%$ of students to at least proficiency and a significant portion to the advanced achievement levels, and sometimes setting the goal of literally doubling student performance.

2) Analyzed student data to become deeply knowledgeable about the status of student performance and the nature of the achievement gap. This step included analysis of state test score results, which provided a "macro" picture of student achievement, as well as analysis of "formative" assessments that gave the schools more detailed and nuanced information about the exact nature of what students did and did not know about the various concepts that were in the states', districts', and schools' content standards that needed to be taught. The formative assessments allowed teachers to tailor their instruction to the precise learning needs of their own students, thus making instruction more effective and using instructional time more efficiently.

3) Reviewed evidence on good instruction and effective curriculum and made decisions on a new instructional program for the site. All the schools threw out the old curriculum and replaced it with a different and more rigorous, and often research-based, curriculum.

4) Invested heavily in teacher training that included intensive 1- to 2-week summer institutes, longer teacher work years, as well as resources for trainers and most importantly, placing instructional coaches in all school. Research shows that it is the instructional coaches who are the critical factor in making professional development work, i.e., leading to change in teachers' instructional practice that is linked to student learning gains.
5) Provided extra help for struggling students that, with a combination of state, local funds and federal Title 1 funds, consisted of some combination of tutoring in a 1-1, 1-3, or 1-5 format, extended-day academic help programs, summer school, and English language development for all ELL students.

6) Created smaller classes in early elementary years, often lowering class sizes in grades $\mathrm{K}-3$ to 15 students, citing research from randomized trials.

7) Used time more productively, often increasing time allocations for some core subjects, protecting classes from interruptions during core class periods, and in secondary schools, offered double class periods in subjects where students were struggling to achieve to standards.

8) In the process created "professional school communities," with teachers working collaboratively on the instructional program and in the formative assessment analyses.

9) Were led at the site by both teachers and principals providing instructional leadership, and supported by the district in their change efforts.

10) Connected the school with the broad range of professional knowledge including research-based curriculum programs, new ways to organize the instructional program, and other research-based best practices, and tapped the knowledge of national experts as well as experts in regional service agencies and state departments of education. And finally,

11) Used programs, strategies, and resource levels that, on average, can be funded with the national average expenditure per pupil, suggesting that with the current revenues in the nation's education system, schools should be able to dramatically increase student academic performance at least in some subject areas and at some grade levels through school restructuring and resource reallocation. 
The schools used the resources in the adequacy model, specifically small classes in grades $\mathrm{K}-3$, heavy investments in professional development including school-based instructional coaches, extra help strategies for struggling students such as 1-1 and small-group tutoring, as well as extended-day programs, etc. We found a high degree of alignment between the resources recommended in Table 1 and the resource needs of the strategies that schools deployed to double performance. In virtually all cases, the schools not only restructured but also engaged in significant resource reallocation.

However, all the examples were of schools that had boosted student performance in just one or two content areas (e.g., reading and mathematics), and at one or maybe two education levels (e.g., elementary and middle school levels), through a combination of new grants and reallocating extant resources. And in most districts, the schools did not have any more resources to reallocate but needed similar resources to produce similar results in all five core content areas and at elementary, middle, and high school levels. The evidencebased recommendations in those states' Table 1 , thus, were focused on identifying the resources needed by all schools to double student performance in the medium term in all core content areas and at all education levels-elementary, middle, and high schools.

\section{Use of Dollars After a School Finance Reform}

Two states, Arkansas and Wyoming, commissioned studies to determine how resources were used in schools after the state had provided significant levels of new funding; policymakers in both states hoped that the new funds would help schools produce improvements in student learning. Using revenues from an increase in the state sales tax, Arkansas provided new funding to local schools for the 2004-05 year. The state implemented an adequacy reform based on an evidence-based school finance adequacy analysis (Odden, Picus, \& Fermanich, 2003b). In Wyoming, the state funded two rounds of increased education dollars in response to a court mandate to fund schools adequately. (Neither Arkansas nor Wyoming policymak- ers put restrictions on local use of school finance reform dollars. And in both states, the legislature was sued shortly afterward, with local educators saying the funding increase was inadequate).

Arkansas legislators wanted to know the degree to which actual resource use paralleled that state's version of Table 1, and commissioned a study to probe that issue. The study analyzed resource use in a random sample of about 105 schools, with the data gathered by on-site interviews of principals and superintendents. Researchers found that schools used resources in ways quite different from the state's recommended uses (Arkansas' version of Table 1) (Odden, Mangan, \& Picus, 2006). These findings were not all that surprising; fiscal federalism would predict that without constraints on the use of funds, schools and districts would use funds in multiple different ways.

There were some central tendencies, however. The study showed that while schools provided lower class sizes, they also provided more electives, less professional development and many fewer instructional coaches, fewer extra help services and very little 1-1 tutoring, and higher teacher salaries than had been included in the Arkansas funding model. Further, Arkansas schools had not improved student performance and thus would be hard pressed to argue that their resource-use practices, different from those in the adequacy funding model, were more effective in producing student learning gains (Odden, 2006).

The expenditure-reporting framework is now being used in a 2-year study of resourceuse practices in all 363 schools in Wyoming. That state's legislature has provided significant new dollars over the past decade including an additional $\$ 200$ million in funding for 2006-07, bringing total K-12 educational revenues to over $\$ 1$ billion for the year. That study, like the successful district study in Washington, also is collecting information on each school's instructional improvement strategy so the results will provide an integrated view of resource use in concert with instructional improvement.

Since the standard fiscal reporting systems do not provide the detailed types of information on resource-use practices that is desired by state policymakers, these studies are 
expensive as school resource-use practices are unearthed only through interviews and document analysis conducted on site in each individual school. Odden and Picus are developing an effort that would redesign state fiscal reporting systems so that these kinds of data, at some point in the near future, could be produced through the standard financial reporting structures (Odden \& Picus, 2006).

The other policy implication is that states should seriously consider placing some restrictions on the use of school finance adequacy dollars. If the state concludes that some specific uses, such as class sizes of 15 in grades $\mathrm{K}-3,1-1$ tutoring, and instructional coaches as part of professional development, will positively impact student learning, then putting dollars for these purposes into a focused categorical program might be a wise policy to ensure that such resources are used for those practices.

\section{Pricing Adequacy Recommendations and Enhancing Teacher Compensation}

Although a related policy brief (Heneman, Milanowski, \& Kimball, 2007) provides an overview of our teacher compensation research, there are aspects of that research that should be mentioned in this school finance context. In the evidence-based approach as well as the professional judgment approach to school finance adequacy, numbers of teacher positions are identified for various educational strategies. In order to provide a cost estimate for the recommendations, a teacher salary needs to be used.

Thus, we conducted research using new federal databases (the O*NET system) to determine what "adequate" teacher salary levels should be, an issue which most adequacy studies have ignored. Our assumption is that not only do the types of educational strategies and thus the number of teacher positions need to be adequate, but also that those teachers need to earn an "adequate" salary in order for the results to lead to a comprehensive and adequately funded state school finance system. In Arkansas and Washington, we compared teacher salary levels to salaries of workers in occupations with similar skills, competencies and job responsibilities to teaching. The Arkansas analysis found that teacher salary levels in that state were below those in similar occupations and recommended a salary increase (Wallace, Odden, \& Picus, 2003). But the Washington analysis found teacher salaries were not below those of similar occupations so did not recommend a teacher salary increase (Imazeki, 2006; Odden et al., 2006).

We have described the methodology for these analyses in more detail in a new handbook for state and local policymakers and a new book on teacher compensation (Odden \& Wallace, 2007a, 2007b). Our general recommendation is that teacher compensation should be comparable to salaries of occupations that require similar competencies and skills as well as job responsibilities.

\section{Synthesis With Policy and Practice Implications}

In short, we believe we have identified many of the key aspects of the education and finance systems that need redesigning in order to align the finance structure more tightly with efforts to improve student learning. We have developed:

1. A better understanding of the use of the education dollar, knowledge that shows that over the past 100 years dollars per pupil after adjusting for inflation have increased about $3.5 \%$ annually, and a realization that although the percent of the dollar spent on instruction has remained the same-about $60-61 \%$ there is a real need to know more about use of the dollar within the instructional category. Our perspective is that understanding the use of resources within the instructional function is a critical step toward understanding how better to use instructional resources to produce higher levels of student academic achievement.

2. With Karen Miles, a procedure for identifying how to capture all of a district's and school's investments in professional development together with ways to redeploy those dollars to more effective strategies.

We would suggest that all districts use this framework to periodically conduct 
a professional development fiscal audit. The audit will identify both the level of investment in ongoing professional development and the foci of those investments. The results will allow most districts, particularly larger districts, to reallocate substantial professional development resources to more intensive programs focused on improving teachers' instructional practice in the core academic subjects of mathematics, science, reading, writing, communication, and history.

3. A new fiscal reporting structure for schools to account for the use of the education dollar within the instructional function by showing expenditures by key educational strategies at the school and district levels, including details of all investments in professional development.

As noted below, we would encourage states to modify their current financial reporting structures to collect these school level-as well as teacher and classroom level-data according to this reporting structure. These new microdata on resource use inside the instructional function would provide much needed data for the policy and practice communities as they seek to know "what works" in education, to engage in evidence-based policymaking and practice actions, and reallocate resources to more effective uses. We recognize that redesigning state fiscal reporting systems along these directions is a large, complex task, and will take time and money, but we believe the results would be worth the effort.

4. An evidence-based (and cost function) strategy to identify an adequate level of resources for prototypical elementary, middle and high schools, as well as districts.

We have concluded that the evidencebased method of determining school finance adequacy is one of the most cost-effective approaches and provides the level and types of resources that should enable most schools to dramatically increase- literally double in many cases - student academic achievement. We would encourage states to consider basing their school finance structure on the results of this approach and we would encourage districts to provide resources to schools according to the same recommendations, whether the resources are provided as staff and dollars and/or through a weighted student formula.

5. An emerging and seemingly robust understanding of what schools can do to double student performance and close the achievement gap.

To make sure these findings apply everywhere, states should sponsor studies of schools that have doubled performance in their states, and incorporate the findings into leadership and other training programs to help spread that knowledge to all districts and schools. States then should recalibrate their school finance structures to provide the resources needed for schools to deploy all the strategies needed to double student performance. The recommendations in the evidence-based approach to school finance adequacy represent a good first step in identifying what these resources are.

6. A way to identify what would be an "adequate" teacher salary level.

We would encourage all states to conduct analyses of the federal O*NET database to identify salaries for workers with knowledge, skills and job responsibilities similar to teachers and seek to ensure that the average teacher salary in the state be approximately at the same level. We also encourage states to provide additional salary premiums for teachers in subject area shortages (e.g., mathematics ands science) and in urban and/or other low-performing schools to ensure that they can compete in the labor market for quality teachers in those subjects and more challenged communities.

7. New approaches to standards-based teacher evaluations that separate teachers into four groups based on their effectiveness with students, and which are good enough to use for consequences, such as teacher pay increases (Odden \& Wallace, 2007a). 
Here we would recommend that states design and help implement these systems, in order to support a statewide vision of good instruction. Performance level 2, as in Connecticut, could be used as the second tier of professional licensure, and all levels could be used to trigger increases in base pay for teachers.

8. New forms of teacher compensation that link the level of pay more to the level of effectiveness in producing student learning, and that encourage teachers to learn and use the types of instructional strategies that are more effective in boosting student learning to higher standards.

9. Proposals for a more strategic humanresource system (Heneman, Milanowski, \& Kimball, 2007).

Our research is now focused on trying to determine "what works" in education. In addition to randomized trials, we also are attempting to identify effective programs and strategies through sophisticated statistical techniques. To this end, we developed an educational framework on the student, classroom/teacher (e.g., a measure of teacher quality, class size, SES of classroom) and school-level (e.g., size, professional development expenditures per teacher, expenditures per pupil for tutors, professional community) factors that impact student learning (Odden, Borman, \& Fermanich, 2004). We use this framework to verify, via hierarchical linear modeling statistical techniques, whether specific variables at these three levels in specific contexts actually are linked to student learning gains, as well as the magnitude of those impacts (for examples, see Archibald, 2006; Fermanich, 2003; Milanowski, Kimball, \& Odden, 2005). Over time, our goal will be to verify not only the positive impacts of the various cost elements in our school-level adequacy models, but also the positive impacts of various curriculum and instructional improvement efforts.

We believe that investigating these important issues inside schools-issues that all schools need to address however they are governed or managed-will provide a key to understanding both programmatically and fiscally how to dramatically improve student achievement, which is the goal of both state standards-based education reform and NCLB.
But in order to produce the data to conduct these types of analyses, we would advise states and districts to restructure their financial reporting systems in ways that incorporate the information in our proposed expenditure framework and the broader recommendations for classroom and teacher data in our data development proposal (Odden \& Picus, 2006).

Finally, we readily admit that more research needs to be conducted on all of these issues. Considerable fine-tuning is needed for all of the above contributions to have the greatest possible effects, including tailoring and adapting each to the specific needs of a particular state, district or school. But the above summary shows that the country is not starting from scratch in its efforts to redesign the finance system in ways that align it with student learning. Tremendous progress already has been made. To move forward, we should use the evidence that we have accrued to develop the second generation of these efforts.

\section{About the Author}

Allan Odden is a Co-Director of CPRE and a Professor of Educational Leadership and Policy Analysis in the School of Education at the University of Wisconsin-Madison. His research and policy analysis focuses on school finance, school finance adequacy, effect use of resources, resource reallocation, and teacher compensation. He is the author of over 200 articles and 30 books and monographs. His most recent publications are School Finance: A Policy Perspective, 4th Edition (McGraw Hill, 2007) with Lawrence O. Picus; How to Achieve World Class Teacher Compensation (Freeload Press, 2007; download at no cost at www.freeloadpress.com ) with Marc Wallace; and Paying for School Finance Adequacy with the National Average Expenditure Per Pupil (Working Paper 2), Seattle: University of Washington, Center on Reinventing Public Education, School Finance Redesign Project (2007) with Michael Goetz and Lawrence O. Picus. 


\section{References}

Archibald, S. (2006). Narrowing in on resources that do affect student achievement. Peabody Journal of Education, 81(4), 23-42.

Archibald, S., \& Gallagher, H. A. (2002). A case study of professional development expenditures at a restructured high school. Education Policy Analysis Archives, 10(29), 124.

Borman, G. D., Hewes, G., Overman, L., \& Brown, S. (2003). Comprehensive school reform and achievement: A meta-analysis. Review of Educational Research, 73(2), 125-230.

Fermanich, M. (2002). School spending on professional development: A cross case analysis of seven schools in one urban district. The Elementary School Journal, 103(1), 27-50.

Fermanich, M. (2003). School resources and student achievement: The effect of school-level resources on instructional practices and student outcomes in Minneapolis public schools. Unpublished Ph.D. dissertation, University of Wisconsin-Madison.

Fermanich, M., Mangan, M. T., Odden, A., Picus, L.O., Gross, B., \& Rudo, Z. (2006, July). Washington Learns: Successful district study (Working draft, prepared for Washington Learns). North Hollywood, CA: Lawrence O. Picus and Associates. Retrieved August 15, 2006, from http://www.washingtonlearns.wa. gov/materials/WALearnsSuccessfulDistrictReport7-13-06.p

Fermanich, M., Picus, L. O., \& Odden, A. (2006). A successful district's approach to school finance adequacy in Washington. Analysis prepared for the K-12 Advisory Committee of Washington Learns. Retrieved March 7, 2007, from http://www.washingtonlearns.wa.gov/materials/SuccessfulDistReport9-11-06Final_000.pdf

Gallagher, H. A. (2002). Elm Street School: A case study of professional development expenditures. Education Policy Analysis Archives, 10(28), 1-32.

Goertz, M. E., \& Duffy, M. (1999). Resource allocation in reforming schools. In M.E. Goertz \& A. Odden (Eds.), School-based
Financing (pp. 215-244). Thousand Oaks, CA: Corwin Press.

Goertz, M. E., \& Hess, G. A., Jr. (1998). Processes and power in school budgeting across four large urban school districts. Journal of Education Finance, 23(4): 490-506.

Heneman, H. G., III, Milanowski, A. T., \& Kimball, S. (2007). Teacher performance pay: Synthesis of plans, research, and guidelines for practice. (CPRE Research Report No. RB46). Philadelphia: Consortium for Policy Research in Education.

Imazeki, J. (2006). Regional cost adjustments for Washington State. Report prepared for the K-12 Advisory Committee of Washington Learns.

Milanowski, A. T., Kimball, S. M., \& Odden, A.R. (2005). Teacher accountability measures and links to learning. In R. Rubenstein, A. E. Schwartz, L. Stiefel, \& J. Zabel, (Eds.), Measuring School Performance \& Efficiency: Implications for Practice and Research, 2005 Yearbook of the American Education Finance Association. Larchmont, NY: Eye on Education.

Miles, K., \& Darling-Hammond, L. (1998). Rethinking the allocation of teaching resources: Some lessons from high-performing schools. Educational Evaluation and Policy Analysis. 20(1), 9-29.

Miles, K., Odden, A., Archibald, S., \& Fermanich, M. (2004). Inside the black box of school district spending on professional development: Lessons from five urban districts. Journal of Education Finance, 30(1), 1-26.

Mohrman, S. (1994). Large scale change. In S. Mohrman \& P. Wohlstetter (Eds.), SchoolBased Management: Organizing for High Performance. San Francisco: Jossey-Bass

National Center for Education Statistics. (2005). NAEP 2004 trends in academic progress: Three decades of student performance. Washington, DC: U.S. Department of Education.

Odden, A. (1997). How to rethink school budgets to support school transformation. Getting Better by Design Series, Vol. 3. Arlington, VA: New American Schools. 
Odden, A. (2003b). Equity and adequacy of school finance today. Phi Delta Kappan, 85(2), 120-125.

Odden, A. (2006). School finance adequacy in Kentucky, Arkansas and Wyoming: Implications for other states. Paper prepared for the California School Finance Adequacy Project.

Odden, A., \& Archibald, S. (2000). Reallocating resources to support higher student achievement: An empirical look at five sites. Journal of Education Finance, 25(4), 545-564.

Odden, A., \& Archibald, S. (2001a). Reallocating resources: How to boost student achievement without spending more. Thousand Oaks, CA: Corwin Press.

Odden, A., \& Archibald, S. (2001b). Committing to class-size reduction and finding the resources to implement it: A case study of resource reallocation in Kenosha, Wisconsin. Education Policy Analysis Archives. 9(30). Retrieved March 7, 2007, from http://epaa. asu.edu/epaa/v9n30.html

Odden, A., Archibald, S., Fermanich, M., \& Gallagher, H. A. (2002). A cost framework for professional development. Journal of Education Finance, 28(1), 51-74.

Odden, A., Archibald, S., Fermanich, M., \& Gross, B. (2003). Defining school-level expenditure structures that reflect educational strategies. Journal of Education Finance, 29(3), 323-356.

Odden, A., Archibald, S., \& Tychsen, A. (2000). Can Wisconsin schools afford comprehensive school reform? Journal of Education Finance, 25(3), 323-342.

Odden, A., Borman, G., \& Fermanich, M. (2004). Assessing teacher, classroom, and school effects, including fiscal effects. Peabody Journal of Education, 79(4), 4-32.

Odden, A., \& Busch, C. (1998). Financing schools for high performance. San Francisco: Jossey-Bass.

Odden, A., Goertz, M., Goetz, M., Archibald, S., Gross, B., Weiss, M., \& Mangan, M. T. (Forthcoming). The cost of instructional improvement: Resource allocation in schools using comprehensive strategies to change classroom practice. Journal of Education Finance.
Odden, A., Goetz, M., \& Picus, L. O. (2007). Paying for school finance adequacy with the national average expenditure per pupil. (Working Paper 2). Seattle: University of Washington, Center on Reinventing Public Education, School Finance Redesign Project.

Odden, A., Mangan, M. T., \& Picus, L. (2006). Level and use of resources in Arkansas: Are use patterns consistent with doubling student performance? Prepared for the Arkansas Senate and House Adequacy Study Oversight Committee.

Odden, A., \& Picus, L. O. (2007). School finance: A policy perspective (4th Ed.). New York: McGraw Hill.

Odden, A., \& Picus, L. O. (2006). Creating an integrated resource information system to assess student, teacher, classroom, and school effects on value-added student learning gains and to support more cost-effective budgeting: A multi-state cooperative project. Madison: University of Wisconsin, Wisconsin Center for Education Research, Consortium for Policy Research in Education.

Odden, A., Picus, L. O., Archibald, S., Goetz, M., Mangan, M. T., \& Aportela, A. (2007). Moving from good to great in Wisconsin: Funding schools adequately and doubling student performance. Madison: University of Wisconsin, Wisconsin Center for Education Research, Consortium for Policy Research in Education.

Odden, A., Picus, L. O., \& Fermanich, M. (2003b). An evidence-based approach to school finance adequacy in Arkansas. Report prepared for the Joint Committee on Educational Adequacy. Little Rock, AR.

Odden, A., Picus, L. O., Goetz, M., Mangan, M. T., \& Fermanich, M. (2006). An evidencebased approach to school finance adequacy in Washington. Report prepared for the K-12 Advisory Committee of Washington Learns. Retrieved March 7, 2007, from http://www. washingtonlearns.wa.gov/materials/EvidenceBasedReportFinal9-11-06_000.pdf

Odden, A., \& Wallace, M. (2007a). How to achieve world class teacher compensation. St. Paul: Freeload Press. Download at no cost at: www.freeloadpress.com./bookDetail.aspx?bI $\mathrm{d}=1077$ 
Odden, A., \& Wallace, M. (2007b). Rewarding teacher excellence: A teacher compensation handbook for state and local policymakers. Madison: University of Wisconsin, Wisconsin Center for Education Research, Consortium for Policy Research in Education.

Thayer, J. L. (2004). Professional development: Costs and effectiveness in one rural district. Ph.D. dissertation prepared at the School of Education, University of Wisconsin-Madison.

Wallace, M. J., Jr., Odden, A., \& Picus, L. (2003). Developing differentiated compensation for teachers. Report prepared for the Joint Committee on Educational Adequacy. Little Rock, AR. 


\section{Nondiscrimination Statement}

The University of Pennsylvania values diversity and seeks talented students, faculty, and staff from diverse backgrounds. The University of Pennsylvania does not discriminate on the basis of race, sex, sexual orientation, religion, color, national or ethnic origin, age, disability, or status as a Vietnam era veteran or disabled veteran in the administration of educational policies, programs, or activities; admissions policies, scholarships, or loan awards; and athletic or University-administered programs or employment. Questions or complaints regarding this policy should be directed to Executive Director, Office of Affirmative Action, 1133 Blockley Hall, Philadelphia, PA 19104-6021 or 215-898-6993 (Voice) or 215-898-7803 (TDD).

\section{About CPRE}

The Consortium for Policy Research in Education (CPRE) studies alternative approaches to education reform in order to determine how state and local policies can promote student learning. Currently, CPRE's work is focusing on accountability policies, efforts to build capacity at various levels within the education system, methods of allocating resources and compensating teachers, instructional improvement, finance, and student and teacher standards. The results of this research are shared with policymakers, educators, and other interested individuals and organizations in order to promote improvements in policy design and implementation.

CPRE unites seven of the nation's leading research institutions to improve elementary and secondary education through research on policy, finance, school reform, and school governance. Members of CPRE are the University of Pennsylvania, Teachers College Columbia University, Harvard University, Stanford University, the University of Michigan, Northwestern University, and the University of WisconsinMadison.

CPRE Policy Briefs are published by CPRE. To learn more about CPRE research or publications, please call 215-573-0700 or access CPRE publications at www.cpre.org; www.wcer. wisc.edu/cpre/; or www.sii.soe.umich.edu.
Graduate School of Education University of Pennsylvania

3440 Market Street, Suite 560

Philadelphia, PA 19104-3325
NON PROFIT

U.S. POSTAGE

PAID

PERMIT NO. 2563

PHILADELPHIA, PA 